Boer, D. de, Delnoij, D. De onderbouwing en het gebruik van kwaliteitsindicatoren. TSG: Tijdschrift voor Gezondheidswetenschappen: 2012, 90(2), 69-70

\begin{tabular}{|c|c|}
\hline Postprint Version & 1.0 \\
\hline Journal website & $\begin{array}{l}\text { http://vb23.bsl.nl/BSL/content/edition/1388- } \\
\text { 7491/edition.asp?custom_product_id=1388-7491\&product_id=\{68B1EBF1- } \\
\text { 7393-458F-BF75-BDB5E9A3DAE9\} }\end{array}$ \\
\hline
\end{tabular}

Pubmed link

DOI

This is a NIVEL certified Post Print, more info at http://www.nivel.eu

\title{
De onderbouwing en het gebruik van kwaliteitsindicatoren
}

\author{
DOLF DE BOER,, DiANA DELNOIJ
}

Het meten van kwaliteit van zorg is essentieel voor het borgen ervan. In het verleden werden de prestaties van de gezondheidszorg vooral gemeten in termen van kosten en productie. Met de introductie van marktwerking in de gezondheidszorg ontstond echter een sterke behoefte aan kwaliteitsinformatie, liefst op het niveau van individuele instellingen. Marktwerking beoogt namelijk concurrentie te bewerkstelligen tussen instellingen en zonder inzicht in de kwaliteit van de geleverde zorg zal deze concurrentie zich beperken tot een concurrentie op prijs. Van een concurrentie op prijs alleen is bekend dat dit in de meeste gevallen ten koste gaat van de kwaliteit. Inzicht in kwaliteit is daarom van groot belang. De afgelopen jaren zijn er dan ook forse inspanningen geleverd om voor verschillende sectoren en aandoeningen indicatoren te ontwikkelen die inzicht geven in de kwaliteit van zorg die binnen afzonderlijke instellingen wordt geleverd. Inmiddels is een grote hoeveelheid indicatoren voor verschillende typen van zorg beschikbaar. Deze indicatoren laten zich grofweg onderscheiden in twee groepen: indicatoren gebaseerd op de registraties van zorgaanbieders (zorginhoudelijke indicatoren) en indicatoren gebaseerd op patiëntervaringen, doorgaans gemeten met Consumer Quality index vragenlijsten (CQ-indicatoren).

\section{VELDPARTIJEN}

Bij de ontwikkeling van kwaliteitsindicatoren was in de afgelopen jaren een belangrijke gedachte dat verschillende veldpartijen, zoals verzekeraars, patiënten- en consumentenorganisaties en brancheorganisaties, overeenstemming bereiken over de indicatoren zodat één meting verschillende doelen kan dienen. De patiëntenorganisaties worden daarin nog wel eens overstemd door verzekeraars en brancheorganisaties met meer mankracht en geld om hun belangen bij de ontwikkeling van indicatoren te behartigen. De bezuinigingen op subsidies aan patiënten- en cliëntenorganisaties maken het voor deze organisaties alleen maar moeilijker. De indicatoren gebaseerd op de CQ-index brengen dit enigszins in evenwicht, niet alleen doordat deze gebaseerd zijn op ervaringen van patiënten zelf, maar ook omdat de selectie van items in de vragenlijsten berust op wat patiënten belangrijk vinden. Op deze manier blijft het patiëntenperspectief geborgd binnen de kwaliteitsindicatoren. Dat is belangrijk, want voor de patiënt is niet alleen de medisch-technische uitkomst van belang, maar ook het proces waarlangs die uitkomst tot stand komt. Niettemin blijft de inbreng van patiënten- en cliëntenorganisaties een punt van aandacht, zeker gezien de beperkte middelen waarover zij beschikken in vergelijking met andere veldpartijen.

De gedachte om verschillende doelen te bedienen vanuit één indicatorenset staat op dit moment wel ter discussie. Zo schrijft een brancheorganisatie in de verpleging, verzorging en thuiszorg op haar website: "De doelen waarvoor gemeten wordt, moeten gescheiden worden: interne verbetering, het geven van cliëntinformatie, toezicht en kwaliteitsinformatie voor zorgkantoren zijn te breed geworden voor de bestaande kwaliteitsmetingen”. 1 Dat is makkelijk gezegd. Maar het is de vraag wat het alternatief is. Zo'n tien jaar geleden was er namelijk juist grote behoefte aan het consensusmodel omdat verschillende partijen destijds hun eigen informatievoorziening regelden met een wildgroei van dataverzamelingen als gevolg. Daarbij kon het ook nog gebeuren dat een instelling in de ene meting goed uit de bus kwam en in een andere meting slecht, wat leidde tot discussies over kwaliteit van data, terwijl het over kwaliteit van zorg had moeten gaan. Gebruik van één basisset aan data die via één loket wordt uitgevraagd, is dus zo gek nog niet. Uiteraard moeten die data wél worden verwerkt tot verschillende informatieproducten. Een kiezende zorgconsument heeft namelijk andere informatie nodig dan een toezichthouder, een zorginkoper of een 
Boer, D. de, Delnoij, D. De onderbouwing en het gebruik van kwaliteitsindicatoren. TSG: Tijdschrift voor Gezondheidswetenschappen: 2012, 90(2), 69-70

professional. Het streven naar overeenstemming over wat wordt gemeten is daarom een verstandige nikeure, hoewel natuurlijk duidelijk is dat partijen onderling wel wat water bij de wijn moeten doen.

\section{BRUIKBAARHEID VAN RESULTATEN}

Veldpartijen geven geregeld aan dat de bruikbaarheid van resultaten niet beantwoordt aan de verwachtingen die zij daarvan hadden. Dat ligt mogelijk ook ten grondslag aan de eerder genoemde discussie over de vele doelen die gediend moeten worden met indicatorensets. Hoe dan ook is dit een essentieel vraagstuk aangezien de indicatoren ontwikkeld zijn om marktwerking te faciliteren en dan moeten de indicatoren wel bruikbaar zijn.

Nu waren die verwachtingen ook wel heel hoog. In de praktijk van de afgelopen jaren kwamen echter problemen met de validiteit en betrouwbaarheid van indicatoren aan het licht die niet - of in ieder geval niet in die omvang - waren voorzien. Ook werden verhitte discussies gevoerd over de wijze van verwerking en analyse van indicatoren, die complexer bleken dan aanvankelijk werd verwacht.

Deze onvoorziene hindernissen hebben de ontwikkeling van indicatoren vertraagd en compliceren tevens de interpretatie van resultaten. Een indicatorscore staat immers niet meer op zichzelf, maar moet worden gewogen aan de hand van de validiteit en betrouwbaarheid van de indicator en het aantal waarnemingen waarop de score is gebaseerd. Voor onderzoekers is dat gesneden koek. Maar ongetwijfeld is het niet wat beleidsmakers voor ogen hadden toen de ontwikkeling van indicatorensets werd ingezet.

Een bijkomend probleem is dat van indicatoren alleen bewerkte en geaggregeerde scores toegankelijk zijn voor alle veldpartijen. Dat werd vaak al uitonderhandeld aan het begin van een traject, nog voordat er één indicatorscore was uitgevraagd. Gaandeweg is gebleken dat partijen ook vaak moeten beschikken over de onderliggende ruwe data op patiëntniveau, om daarvan informatie te kunnen maken die voor hun doel geschikt is. Maar die zijn vaak slechts voor één van de partijen toegankelijk, namelijk voor degene die de data aanlevert of - in het geval van de CQ-index - voor de dataverzameling betaalt.

Het beter toegankelijk maken van ruwe data, uiteraard met inachtneming van privacyrichtlijnen, zou veel kunnen opleveren. Veldpartijen kunnen dan bekijken of zij van de ruwe data misschien meer kunnen leren dan van de bewerkte data, die veelal sterk vereenvoudigd zijn omdat zij gericht zijn op presentatie als keuze-informatie op websites. Daarnaast stelt het wetenschappers in staat om te onderzoeken hoe de vruchten van deze data zo goed mogelijk voor verschillende doeleinden kunnen worden geplukt. Het nadeel is dat er ook meer inzicht ontstaat in de beperkingen van de data. Dat zou het aanzien van de indicatoren kunnen schaden. Maar uiteindelijk zullen de indicatoren er beter en bruikbaarder van worden omdat meer partijen en experts zich er actief mee kunnen bemoeien.

\section{KWALITEITSINSTITUUT}

Dit jaar wordt een kwaliteitsinstituut opgericht dat per 1 januari 2013 operationeel moet zijn en ervoor moet zorgen dat indicatoren worden (door-) ontwikkeld en gemeten. De bestuurlijke inbedding van kwaliteitsmetingen gaat daarmee ingrijpend veranderen, niet alleen omdat bestaande instanties opgaan in dit instituut, maar ook omdat de verantwoordelijkheid voor kwaliteitsmetingen veel meer bij de veldpartijen komt te liggen dan nu het geval is. $\underline{2}$ De wijze waarop dit kwaliteitsinstituut precies wordt ingericht is ten tijde van het schrijven van dit redactioneel nog niet bekend. Duidelijk is wel dat de betrokkenheid van veldpartijen in het algemeen en patiënten- en consumentenorganisaties in het bijzonder de nodige aandacht verdient in de nieuwe structuur. Daarbij is de bruikbaarheid van indicatoren een essentiële voorwaarde die vereist dat er blijvend gewerkt wordt aan de wetenschappelijke onderbouwing van indicatoren. Want indicatoren die niet valide of betrouwbaar zijn, zijn niet bruikbaar. Het is daarom ook te hopen dat wetenschappelijk onderzoek een prominente plaats krijgt in de taakomschrijving van dat nieuwe kwaliteitsinstituut.

\section{LITERATUUR}

1. ActiZ. Kwaliteit anders meten. Utrecht: ActiZ, 2011

http://www.actiz.nl/nieuwsberichten/website/nieuws/kwaliteit-anders-meten

2. Ministerie van Volksgezondheid, Welzijn en Sport. Beleidsagenda 2012. Den Haag: Ministerie van VWS, 2012. 